REGULAR ARTICLE

\title{
PRICING ATTRIBUTES OF WINES FROM EMERGING SUPPLIERS ON THE BRITISH COLUMBIA MARKET
}

\author{
Veronica YOO ${ }^{1}$, wojciech J. FLORKOWSKI ${ }^{2 *}$, Richard CAREW ${ }^{3}$
}

\author{
Address: \\ ${ }^{1}$ Former graduate student, Department of Agricultural and Applied Economics, University of Georgia, Athens, \\ Georgia \\ 2* Professor, Department of Agricultural and Applied Economics, University of Georgia, Griffin Campus, 1109 \\ Experiment Street, Griffin, GA 30223-1797 \\ ${ }^{3}$ Bioeconomist, Agricultural and Agri-Food Canada, Pacific Agri-Food Center, Summerland, British Columbia, \\ Canada. \\ *Corresponding Author; e-mail: wojciech@uga.edu
}

\begin{abstract}
We examine British Columbia (BC) wine consumers’ valuation of wine imported from emerging suppliers (Argentina, Bulgaria, Chile, Croatia and Hungary) using hedonic pricing technique. BC Liquor Distribution Branch retail sales data covering weekly sales of table wine imported into the province of British Columbia from all five countries for the period April 20 $0^{\text {th }}, 2002$ to May $8^{\text {th }}, 2004$ are applied to estimate the influence of wine attributes on prices. The results indicate that grape variety, brand name, country of origin, and alcohol content are important factors influencing prices paid by consumers. In particular, Chilean white and red wines are associated with larger price premia as compared to Argentinean wines. Wines from Hungary, Bulgaria, and Croatia, although sold in large quantities in the BC market, are substantially discounted in comparison to New World wines. Cabernet Sauvignon fetches a higher price when blended with other varietals and Chardonnay appears to be popular and highly valued by consumers among white wines.
\end{abstract}

Keywords: wine, objective characteristics, hedonic pricing, emerging suppliers, New World wine suppliers.

JEL: Q13

\section{INTRODUCTION}

British Columbia (BC), the second largest grape growing province in Canada, behind Ontario, is also a major producer and a major consumer of wine. Per capita wine sales in BC have shown a significant growth of 39 percent between 2001 and 2009, and volume growth of wine sales at 57 percent outpaced that of spirits and beer combined (Statistics Canada, 2011). Even though BC has been growing superior grapes that have resulted in higher quality wines, imports from the so-called Old World and New World producing countries still appear to be necessary to satisfy the taste and preferences of BC consumers. In fact, sales volume of imported wine increased by 69 percent between 2001 and 2009, while that of domestic wine increased by 50 percent (Statistics Canada, 2011).

The $\mathrm{BC}$ wine market is changing rapidly, and so are its players. While New World wine producers such as Australia and the United States are the main sources of imported wine in BC, new producers from South America, and Central and Eastern Europe are gaining market share. To fill the gap in knowledge of pricing wine from emerging suppliers, this study focuses on table wine imports from Chile, Argentina, Hungary, Bulgaria, and Croatia. Argentina and Chile are considered New World countries according to the wine lexicon (Foster and Spencer 2002), and their wines have gained significant international reputation in the last ten to fifteen years. On the other hand, Bulgaria, Croatia and Hungary do not fall into any wine-related category per se, but international economics experts often refer to them as "transition economies." Ever since the disintegration of the Soviet Union and, later, the accession of Hungary (in 2004) and Bulgaria (in 2007) to the European Union (EC), their wine industries have reemerged and slowly gained international competitiveness (Noev and Swinnen, 2001). We consider all five countries to have the status of "an emerging supplier" in the $\mathrm{BC}$ wine market, and thus, refer to them as 'emerging wine countries' throughout this paper. The wines produced from South America are likely to differ from those in Central and Southeast Europe in terms of the varieties planted, vineyard conditions, wine styles and the structure of wine ownership. For example, winemakers over the years in the Balkan countries, such as Hungary have invested into cellar equipment improvement and expanded plantings of internationally recognized grape varieties.

This paper extends the existing literature on wine studies by estimating a hedonic price function for wine imported by BC from emerging suppliers. Few studies in the empirical literature (Noev, 2005; San Martin, Brummer and Troncoso, 2008; Luppe, Favero and Belfiore, 2009) have employed hedonic pricing techniques to measure the quality attributes of South 
American or Balkan wines. The first and general objective of this paper is to estimate a hedonic pricing model for wine imported from the five emerging countries in the BC wine market. Second, we examine the relationship between the price of wine and its various attributes (e.g., color, grape variety, brand name elements, country of origin and alcohol content) and identify attributes that are statistically significant in determining prices. Study results reflect consumer valuation of wine attributes and thus, provide knowledge about consumer preferences and purchase behavior for wine traders and distributors and retailers' merchandising and purchasing strategies. Importers may apply the new consumer knowledge indecisions to source wine recognizing its market potential and emphasizing specific attributes consumers have shown to value. Exporters from the emerging wine supplying countries gain insights about their relative strong attributes of their wines to adapt marketing strategies to the BC market.

The remainder of this paper is structured as follows. Section II presents an overview of the wine market in British Columbia. In Section III we provide a brief review of the literature on hedonic pricing models and their application to wine. Section IV describes the methodology and data used for our estimation. Section V discusses the empirical results for the estimated models, and the final section summarizes the main findings of this study and describes some marketing and policy implications.

\section{Overview of the British Columbia Wine Market}

Although Canada is not a major wine maker compared to other developed countries (e.g., Italy, France), its wine industry has undergone major positive changes. Growing consumer and production demand, the advent of the North American Free Trade Area, new investments in vineyards and wineries along with government support (Agriculture and Agri-Food Canada, 2009) have all contributed to the gradual growth of the industry.

British Columbia, one of Canada's leading wine regions, planted its first grapevines in the 1860s although commercial wine making did not start until 1930s. In the premature stages of production, producers were focused on making dessert and fortified wines (Williams and Dossa, 2003). Over the years, production has not only expanded to more than sixty group varietals including
Merlot, Pinot Noir and Chardonnay, but it has also improved in terms of quality. Part of this improvement can be attributed to the creation of the Vintners Quality Alliance (VQA), a national premium wine standard that regulates domestic production practices, quality and labeling. Between 2000 and 2005, the number of existing wineries almost doubled increasing from 60 to 119 wineries. During the same period, sales of wine in BC experienced a similar increase rising from CDN\$48.7 million to almost CDN\$115 million (BC Wine Institute, 2011). Moreover, the introduction of regional appellations and even sub-appellations in BC, which is comparable to the concept of European "terroir," gives evidence of the province's evolving sophistication in the winemaking field. Despite the unquestionable success and steady expansion of the domestic wine industry in British Columbia, local consumers still seem to purchase imported wine in significant and increasing quantities. Between 2002 and 2006, the consumption of domestic wine rose by 17 percent while that of imported wine rose by 28 percent (British Columbia Liquor Distribution Branch, 2007).

Even though Australia and the United States are the top suppliers of imported wine in British Columbia, countries, such as Chile, Argentina, Hungary and Croatia have been increasing their market share (Table 1). Within the group of emerging suppliers considered in this study, Chile and Argentina have promoted their products more aggressively and thus, have captured larger portions of the market. Croatia, Bulgaria and Hungary, on the other hand, have undergone different wine development paths primarily due to their heritage of rigid government control of the economy. Their communist regimes protected the wine sector quite heavily, and state intervention was still latent throughout the 1990s (Sidlovits and Kator, 2007). During the period of transition, these countries experienced a series of changes such as the vineyard restructuring, land privatization and acquired the new know-how. In addition, Bulgaria and Hungary started to receive additional funds after their accession to the EU. Evidently, these countries are trying to re-emerge in the global market embracing a competitive market strategy and adopting improved technology and fruit-driven wine styles to produce standard varietal wines.

Table 1 British Columbia wine (grape wine \& grape must) imports from Chile, Argentina, Hungary, Bulgaria and Croatia, 2001-2010, in CDN\$ Million

\begin{tabular}{rrrrrrr}
\hline Year & Chile & Argentina & Hungary & Bulgaria & Croatia & Total (all countries) \\
\hline 2001 & 11.46 & 1.28 & 0.34 & 0.30 & 0.064 & 90.55 \\
2002 & 10.98 & 1.32 & 0.42 & 0.24 & 0.054 & 103.89 \\
2003 & 10.86 & 1.45 & 0.38 & 0.25 & 0.061 & 109.71 \\
2004 & 11.76 & 2.26 & 0.54 & 0.12 & 0.053 & 124.58 \\
2005 & 10.83 & 3.34 & 0.45 & 0.16 & 0.050 & 138.44 \\
2006 & 12.63 & 4.18 & 0.36 & 0.088 & 0.008 & 162.14 \\
2007 & 17.45 & 6.90 & 0.39 & 0.025 & 0.032 & 189.23 \\
2008 & 20.79 & 8.91 & 0.42 & 0.003 & 0.026 & 216.30 \\
2009 & 18.05 & 12.12 & 0.44 & N/A & 0.005 & 172.76 \\
2010 & 16.60 & 11.99 & 0.76 & N/A & 0.016 & 178.44 \\
\hline
\end{tabular}

Note: Wine imports [HS code, 2204] included table, sparkling, and fortified wines.

Source: Industry Canada. Trade data online, 2015. 


\section{MATERIALS AND METHODS}

An extensive body of studies has analyzed the relationship between prices and product attributes through hedonic price models. Waugh (1928) pioneered the measurement the effect of quality factors on prices of asparagus, tomatoes and cucumbers. The results placed value on vegetable characteristics. Later, several more studies, including the seminal paper by Rosen (1974), believed to have established the theoretical foundation of hedonic price analysis, applied that technique. Rosen suggested that consumers pay an implicit price for each quality attribute of a given good, and the sum of the implicit prices translates into observed market prices.

Wine is a highly differentiated product and an appropriate candidate for hedonic techniques. The existing wine pricing literature distinguishes among three different sets of variables that affect prices of wine. The most widely studied category consists of the so-called objective attributes such as grape variety, appellation of origin, harvest year (vintage), name of a brand, and alcohol content to name a few. Focusing on the effect of grape variety on wine prices, Golan and Shalit (1993) evaluated quality characteristics of Israeli wines using the hedonic approach and developed a producer pricing schedule. Information about objective attributes is placed on bottle labels and consumers are aware of primary quality attributes at the point of purchase. Oczkowski (1994) incorporated in his hedonic model the grape style, grape region, grape vintage and producer size. All of the variables significantly contributed to the explanation of price differences of Australian wines.

The other two sets of factors that influence wine quality are based on sensory evaluation and reputation of wines. Probably the most cited study within the first category is by Combris, Lecocq and Visser (1997), who employed a hedonic model for Bordeaux and, later, Burgundy (2000) wines using data from an independent panel of tasters. Based on both label and sensorial characteristics, the study of Bordeaux wine prices concluded that objective attributes appeared to be superior indicators of price variations compared to sensorial attributes, while the Burgundy wine price study found the latter attributes somewhat significant. Consequently, the evidence of effects of sensory wine characteristics is ambiguous. The authors ascribe the inconclusiveness to the existence of imperfect information and the high transaction costs associated with the acquisition of data on sensorial variables. The third set of factors focuses on the importance of reputation (Shapiro, 1983) of wines and wine producers. Landon and Smith (1997) pioneered the application of such factors in the wine price analysis. They expanded previous studies by adding a single and collective wine reputation measure as an explanatory variable for price variation. They concluded that the long-term reputation is a superior determinant of consumers' valuation of wine to short-term quality factors. A more recent study by Benfratello, Piacenza, and Sacchetta (2009) on vintage Italian wines found further evidence supporting the effects of reputation on wine price.

\section{Data}

The study employs British Columbia Liquor Distribution Branch retail stores wine sales data. The latter covers weekly retail sales of imported table wine in 0.750 liter bottles from Argentina, Bulgaria, Chile, Croatia and Hungary for 108 weeks over the period from April 20, 2002 to May 8, 2004. Thus, the total number of observations is 26,375. Wine prices in the sample represent actual transaction rather than suggested prices. All prices are expressed in constant 2002 Canadian dollars using the Canadian CPI for wine purchased from retail stores as deflator (Statistics Canada, 2005). In addition to prices, attributes for wine such as grape variety (VARIETY), color, brand name elements (BRAND), country of origin (COUNTRY), quantity sold (QUANTITY), and alcohol content (ALCOHOL) are obtained from the dataset.

Tables 2 and 3 provide a summary of the descriptive statistics. The variables BRAND, VARIETY and COUNTRY are treated as dummy variables given their dichotomous nature. There are 21 grape varietals and 70 company brand names associated with red wines, while there are 11 grape varietals and 36 company brand names within the white wine category. Varieties and brands with less than 30 observations were aggregated to form the "other variety" and "other producer" categories. There is a clear prevalence of red wine in the data considering that 73 percent of wine imported from all five regions is the red wine. The uneven distribution also explains the much larger number of company brand names applied to red wines compared to that of white wines. Furthermore, it can be noted that while Argentina and Chile supply commonly known varietals such as Cabernet Sauvignon, Chardonnay or Malbec, the three other countries supply native single varietals (e.g., Bulgaria's Gamza) or native grape blends (e.g., Hungary's Egri Bikaver and Croatia's Kastelet). The descriptive statistics by country of origin indicate that Chile captures the largest market share in terms of volume among all five countries. The variables QUANTITY and ALCOHOL are continuous variables and represent number of bottles sold each week and alcohol content per bottle of wine, respectively.

\section{The Specification of the Empirical Model}

The hedonic price analysis assumes that consumer preferences apply to the attributes of goods rather than on the actual market goods. Under this assumption, two units of identical goods should carry the same price. However, let us consider a different scenario in which one of the goods has a particular attribute that is valued by consumers. Then, the difference in price between the two goods, ceteris paribus, should represent consumers' willingness to pay for that particular attribute (Rosen, 1974). We propose that a bottle of wine embraces a bundle of $m$ objective attributes, which are represented by a vector $\mathrm{z}$. Then, the price of the good becomes an implicit price function defined by Eq. 1 . 
Table 2 Descriptive and Simple Statistics of Red Wines from Emerging Suppliers on the British Columbia Market

\begin{tabular}{|c|c|c|c|c|c|}
\hline Variable/category & $\mathrm{N}$ & Units & Mean & Minimum & Maximum \\
\hline Price & 19,439 & CDN\$ & 16.38 & 4.00 & 125.95 \\
\hline Alcohol content & 19,439 & Percent & 12.93 & 11.00 & 14.70 \\
\hline Quantity sold (per week) & 19,439 & Bottles & 182.00 & 0.00 & $4,745.00$ \\
\hline \multicolumn{6}{|l|}{ Variety or blend } \\
\hline Bonarda & 108 & Bottles & 10.28 & 10.28 & 10.28 \\
\hline Cabernet Franc & 71 & “ & 22.78 & 17.95 & 23.49 \\
\hline Cabernet Merlot & 656 & “ & 13.21 & 5.65 & 30.62 \\
\hline Cabernet Sauvignon & 6,607 & “ & 16.63 & 4.00 & 75.99 \\
\hline Cabernet Carmenere & 304 & “ & 33.73 & 20.58 & 99.90 \\
\hline Cabernet Syrah & 222 & “ & 20.30 & 10.40 & 48.63 \\
\hline Carmenere & 333 & “ & 8.99 & 8.99 & 8.99 \\
\hline Carmenere Merlot & 105 & “ & 27.99 & 27.99 & 27.99 \\
\hline Dingac & 86 & “ & 24.38 & 24.38 & 24.38 \\
\hline Egri Bikaver & 108 & “ & 7.99 & 7.99 & 7.99 \\
\hline Gamza & 108 & “ & 6.85 & 6.85 & 6.85 \\
\hline Kastelet & 108 & “ & 8.11 & 8.11 & 8.11 \\
\hline Malbec & 2,100 & “ & 17.54 & 5.85 & 125.95 \\
\hline Malbec Blend & 108 & “ & 19.99 & 19.99 & 19.99 \\
\hline Malbec Cabernet & 202 & “ & 14.56 & 12.95 & 16.40 \\
\hline Mavrud & 75 & “ & 5.50 & 5.50 & 5.50 \\
\hline Merlot & 5,247 & “ & 14.66 & 4.95 & 84.95 \\
\hline Merlot Malbec & 108 & “ & 7.99 & 7.99 & 7.99 \\
\hline Merlot Mourvedre & 108 & “ & 13.99 & 13.99 & 13.99 \\
\hline Pinot Noir & 568 & “ & 17.37 & 7.95 & 54.95 \\
\hline Plavac & 108 & “ & 11.02 & 11.02 & 11.02 \\
\hline Red Blend & 183 & “ & 40.00 & 18.50 & 73.99 \\
\hline Red Bordaux Blend & 216 & “ & 27.47 & 24.95 & 29.99 \\
\hline Sangiovese & 108 & “ & 12.99 & 12.99 & 12.99 \\
\hline Sangiovese Bonarda & 99 & “ & 7.17 & 7.17 & 7.17 \\
\hline Syrah & 1,393 & “ & 15.16 & 8.24 & 88.43 \\
\hline Other & 182 & “ & 32.77 & 4.95 & 69.00 \\
\hline \multicolumn{6}{|l|}{ Brand } \\
\hline Altos & 138 & Bottles & 27.16 & 20.95 & 34.57 \\
\hline Aresti & 78 & “ & 14.54 & 12.99 & 21.99 \\
\hline Badel & 194 & “ & 16.94 & 11.02 & 24.38 \\
\hline Calina & 106 & “ & 10.30 & 9.99 & 19.50 \\
\hline Caliterra & 474 & “ & 16.06 & 11.37 & 73.99 \\
\hline Vinas Carmen & 901 & “ & 23.14 & 12.50 & 50.95 \\
\hline Casa Rivas & 91 & “ & 17.05 & 14.35 & 20.58 \\
\hline Casablanca & 138 & “ & 13.75 & 12.95 & 22.62 \\
\hline Concha y Toro & 1,278 & Bottles & 16.76 & 7.95 & 54.95 \\
\hline Cono Sur & 352 & “ & 11.32 & 9.99 & 27.61 \\
\hline Cousino Macul & 291 & “ & 17.32 & 13.99 & 39.95 \\
\hline Dalmacijavino & 118 & “ & 8.12 & 8.11 & 8.24 \\
\hline Diego Murillo & 216 & “ & 11.99 & 11.99 & 11.99 \\
\hline Domaine Boyar & 108 & “ & 8.49 & 8.49 & 8.49 \\
\hline Dona Paula & 262 & “ & 16.05 & 13.95 & 36.95 \\
\hline Dunavar & 108 & “ & 9.49 & 9.49 & 9.49 \\
\hline Egervin & 108 & “ & 7.99 & 7.99 & 7.99 \\
\hline Errazuriz & 365 & “ & 18.67 & 13.43 & 56.99 \\
\hline Esmeralda & 369 & “ & 29.89 & 19.56 & 125.95 \\
\hline Etchart & 129 & “ & 14.15 & 11.95 & 14.40 \\
\hline Finca Flichman & 688 & “ & 15.08 & 6.95 & 69.00 \\
\hline Floresta & 94 & “ & 30.62 & 30.62 & 30.62 \\
\hline Gracia & 216 & “ & 13.38 & 13.38 & 13.38 \\
\hline Haras & 62 & “ & 19.60 & 19.60 & 19.60 \\
\hline Hungarovin & 38 & “ & 4.92 & 4.00 & 5.00 \\
\hline Kendall Jackson & 174 & “ & 29.29 & 14.95 & 59.95 \\
\hline La Rosa & 232 & “ & 11.18 & 8.99 & 15.75 \\
\hline Lapostolle & 457 & “ & 29.94 & 18.49 & 84.95 \\
\hline Lovico Suhindol & 399 & “ & 7.04 & 4.95 & 9.78 \\
\hline Luigi Bosca & 207 & “ & 22.90 & 21.95 & 23.95 \\
\hline Lurton & 229 & “ & 10.75 & 6.95 & 12.32 \\
\hline Marcus James & 324 & “ & 8.79 & 8.79 & 8.79 \\
\hline Martin Santos & 216 & “ & 9.59 & 9.59 & 9.59 \\
\hline Miguel Torres & 195 & “ & 21.85 & 17.90 & 46.90 \\
\hline Montes & 428 & “ & 24.51 & 14.95 & 88.43 \\
\hline
\end{tabular}




\begin{tabular}{lrrrrr}
\hline Variable/category & $\mathrm{N}$ & Units & Mean & Minimum & Maximum \\
\hline Nieto Senetiner & 244 & “ & 14.12 & 12.95 & 45.63 \\
Norton & 323 & “ & 14.32 & 12.99 & 14.99 \\
Odjfell & 174 & “ & 16.38 & 13.90 & 17.90 \\
Penaflor & 216 & “ & 9.66 & 7.99 & 11.33 \\
Portlal del Alto & 173 & “ & 8.97 & 8.95 & 12.95 \\
Rothschild & 118 & “ & 24.31 & 16.95 & 24.95 \\
San Pedro & 578 & “ & 11.95 & 7.95 & 17.55 \\
Santa Amelia & 201 & “ & 10.97 & 10.90 & 11.90 \\
Santa Anna & 204 & “ & 8.74 & 8.73 & 8.75 \\
Santa Carolina & 404 & “ & 11.78 & 8.24 & 4.63 \\
Santa Isabela & 216 & “ & 9.04 & 8.80 & 9.29 \\
Santa Rita & 588 & “ & 18.08 & 11.95 & 75.99 \\
Septima & 79 & “ & 13.49 & 13.49 & 13.49 \\
Tarapaca & 474 & “ & 13.56 & 11.99 & 19.65 \\
Terra Andina & 118 & “ & 11.22 & 8.95 & 19.95 \\
Tolten & 180 & Bottles & 17.93 & 12.50 & 23.53 \\
Trapiche & 255 & “ & 14.36 & 11.49 & 50.61 \\
Trivento & 410 & “ & 10.76 & 5.95 & 25.62 \\
Undurraga & 522 & “ & 14.31 & 9.95 & 35.99 \\
Valdivieso & 1,545 & “ & 20.21 & 11.33 & 54.95 \\
Valentin Bianchi & 197 & “ & 11.95 & 9.95 & 14.95 \\
Veramonte & 366 & “ & 19.30 & 14.95 & 27.99 \\
Vina Bisquertt & 112 & “ & 9.55 & 8.25 & 14.90 \\
Vinprom & 264 & “ & 8.82 & 4.95 & 11.95 \\
Walnut Crest & 221 & “ & 10.92 & 9.95 & 10.95 \\
Weinert & 405 & “ & 24.60 & 17.95 & 119.90 \\
Zuccardi & 64 & “ & 13.64 & 13.38 & 30.45 \\
\hline
\end{tabular}

$P(z)=f\left(z_{1}, z_{2}, z_{m}\right)$

We assume markets are perfectly competitive and, given a certain budget constraint, consumers have made their utility-maximizing choices. The derivative of the hedonic price function with respect to each attribute equals the marginal willingness-to-pay for a change in that attribute, thus taking the form (Eq. 2).

$\partial \mathrm{P} / \partial \mathrm{z}_{\mathrm{i}}=\mathrm{P}_{\mathrm{i}}=\left[\left(\mathrm{U} / \mathrm{z}_{\mathrm{i}}\right) /(\mathrm{U} / \mathrm{x})\right] \mathrm{i}$

The next step is to identify the appropriate functional form. Even though there is little theoretical guidance regarding which functional form suits well hedonic pricing models, previous work (Oczkowski, 1994, 2001; Nerlove, 1995; Schamel and Anderson, 2003; Troncoso and Aguirre, 2006; Carew and Florkowski, 2010) has led researchers to choose the log-linear form. We estimate separate equations for red and white wines expecting varied effects of similar categories of variables because beside the wine color, white and red wines are made from distinctly different grape varieties, among others. The empirical model specification (Eq. 3)

$\operatorname{Ln}\left(\mathrm{P}_{\mathrm{it}}\right)=+\beta_{1}\left(\right.$ VARIETY $\left._{\mathrm{it}}\right)+\beta_{2}\left(\right.$ BRAND $\left._{\mathrm{it}}\right)+\beta$ ${ }_{3}\left(\right.$ COUNTRY $\left._{\text {it }}\right)+\beta_{4}\left(\right.$ ALCOHOL $\left._{\text {it }}\right)+\beta_{5} \operatorname{Ln}\left(Q_{\text {UUANTITY }}\right)+$ $\beta_{6}\left(S_{E A S O N}\right)+\beta_{7}\left(H O L I D A Y_{\text {it }}\right)+\mathrm{u}_{\mathrm{it}}$

where the betas $(\beta)$ are the unknown parameters associated with each wine attribute and $\mathrm{u}_{\mathrm{it}}$ is the random error term. The dependent variable, Ln $\left(\mathrm{P}_{\mathrm{it}}\right)$, represents the natural logarithm of the observed price in CDN\$. The group of explanatory variables is comprised of a combination of continuous and discrete variables.
The inclusion of the variable VARIETY as a determinant of price deems appropriate as the variety of grape is considered to have an important effect on the style and taste of the wine (Landon and Smith, 1998). According to previous studies (Yue, Marette, and Beghin, 2006; San Martin, Brummer, and Troncoso, 2008; Ortuzar-Gana and Alfranca-Burriel, 2010), producers from the New World or emerging wine countries have relied mainly on grape variety and company brand names to signal quality products. Brands can take the form of the producer name (e.g., Chile's Santa Rita), the winery name (e.g., Bulgaria's Lovico Suhindol), or a corporate brand name (e.g., Australia's Yellow Tail). The producer/winery name represents most brands in the current study. Following Costanigro, Mccluskey, and Mittelhammer (2007), Carew and Florkowski (2008) and Kwon, Cyr, Kushner, and Tomson (2010), the natural logarithm of the variable QUANTITY acts as a proxy for the supply of wine available at the time of purchase. A negative relationship is expected between quantity and price as economic theory dictates. The variable $A L C O H O L$ is expected to have a positive relationship with wine prices, especially red wine prices.

Additional dummy variables account for factors that could affect the number of wine bottles sold each week. Therefore, a set of dummy variables was added to capture the effect on wine sales of the four seasons of the year (SEASON) and festive holidays such as Christmas and New Year (HOLIDAY).

In order to avoid the so-called "dummy variable trap" that can result in collinearity among explanatory variables (Belsley, Kuh, and Welsch, 1980) a base variable was omitted in each group of binary variables. The omitted or benchmark binary variables are: Cabernet 
Sauvignon for the category of variables indicating grape variety, Chile for the category of variables indicating the country of origin, and "Valdivieso" for the category of variables describing the brand name in the red wine sample. In the white wine sample, the omitted variables are Chardonnay, Chile, and "Concha y Toro", respectively. The chosen reference variables had the largest number of observations in their respective groups. Summer was chosen as the reference variable in the group of binary variables for seasons of the year.

Next, the testing for the existence of multicollinearity involved the calculation of the correlation matrix and variance inflation factors (VIF). Correlation coefficients do not indicate a problem discarding the possibility of unreliable standard errors, while the VIF values are under the critical threshold value of ten. The test for the presence of heteroscedasticity included both graphic (plots of residuals vs. predicted values) and non-graphic (the Breusch-Pagan test) methods. Results of both tests confirm the presence of heteroscedastic error variances. Therefore, the specified equations are estimated using Ordinary Least Squares (OLS) using the heteroscedasticity consistent covariance matrix (HCCM).

\section{RESULTS AND DISCUSSION}

\section{Red Wine Prices}

Table 4 shows estimated results of the hedonic price equation for red wines. The adjusted $\mathrm{R}^{2}$ is high and $\mathrm{F}$ values indicate a reasonable explanatory power of the specified model. All grape varietals except for Merlot Mourvedre have estimated coefficients that are significant at least at the ten percent significant level indicating that grape varieties influence the price. The largest effect is associated with "Red Blends", which are wines made with red varietals in unique and fine combinations. Another blended wine, "Red Bordeaux Blend" commands the second highest price premium followed by the Chilean cultivar, Carmenere. These three varietals appear to sell at a premium in the BC market due to their exclusiveness and costly winemaking process (San Martin, Brummer, Troncoso, 2008). Other grape varieties commanding premiums, although much lower, include Cabernet Carmenere, Cabernet Malbec, Cabernet Syrah and Malbec at 28, 11, 4 and 2 percent, respectively. The coefficients show that wines that combine Cabernet Sauvignon with other varietals might be more appealing to the taste of BC consumers, and hence, are able to command a higher price. On the other hand, the Croatian Kastelet and Bulgarian Gamza are associated with large negative effects on price as compared to the Chilean Cabernet Sauvignon.

The role of the origin is significant in case of all five regions (Table 1). Such result is consistent with previous studies that incorporated the country of origin as an explanatory variable (Steiner, 2004). Wines from Argentina, Bulgaria, Croatia and Hungary are sold at a discount compared to those from Chile. Argentina, possibly the closest competitor to Chile, commands the lowest discount, while wines from Bulgaria command the highest discount.
Results indicate that different brands sell at a discount or premium compared to the reference brand "Valdivieso" from Chile. The majority of coefficients are highly significant meaning that BC consumers value this particular wine attribute. Seasonal effects and the HOLIDAY variable also appear to have an impact on prices. All binary variables accounting for seasons or holidays are statistically significant at least at the five percent level compared to the benchmark summer season. Demand for red wine peaks in the fall, when red wine sells at a premium compared to the prices in summer. The nature of the season reflected in the weather pattern and the type of food favors red wine consumption in the fall and winter.

Regression results indicate a positive relationship between alcohol content and red wine prices implying that $\mathrm{BC}$ consumers are willing to pay price premia for red wines with higher alcohol content. Carew and Florkowski (2008) showed similar results for Australian wines in the $\mathrm{BC}$ market. Consistent with the prediction of economic theory, the confirmed inverse relationship between prices of red wine and volume suggests that scarcity leads to higher prices.

\section{White Wine Prices}

Table 5 shows coefficient estimates for the group of white wines. The measure of goodness-of-fit, the adjusted $\mathrm{R}^{2}$, indicated that 79 percent of variation in observed prices was explained by the specified model. The significance of the estimated coefficients for grape varietals indicates that the variety of the grape matters in the consumer decision making when purchasing white wine. All grape variety coefficients are relative to the benchmark variety of Chardonnay and measure the percentage price premium or discount that other grape varieties bring with respect to the reference variable. Considering that Chardonnay presents the highest average price of all white wines it is not surprising to see that most of the varieties earn a price discount. BC consumers appear to have a special preference for Chardonnay and other white wine grape varietals must be marketed using specially developed messages stressing variety-specific characteristics. Among white wine grape varietals, Furmint is associated with the largest price discount at 71 percent, followed by Harslevelu and Hemus at 34, and 29 percent, respectively. Pinot Grigio has not been discounted as compared to Chardonnay, indicating that $\mathrm{BC}$ consumers appreciate this particular grape variety.

The country of origin effect on white wine prices follows a pattern similar to the one established for red wines. The coefficients for wines from all countries are statistically significant and indicate price discounts compared to wines from Chile. Once again, Argentinean wines are associated with the lowest discount, while Bulgarian wines bring the highest discount followed by Hungary and Croatia. The wines from the Balkan countries bring a discount as compared to the benchmark country possibly because they are not known to BC consumers as suppliers of wine. The majority of brand names are price discounted with respect to the popular (Van Tienhoven, 2008) Chilean brand "Concha y Toro”. 
Table 3 Descriptive and Simple Statistics of White Wines from Emerging Suppliers on the British Columbia Market

\begin{tabular}{|c|c|c|c|c|c|}
\hline Variable/category & $\mathrm{N}$ & Units & Mean & Minimum & Maximum \\
\hline Price & 6,875 & CDN\$ & 12.63 & 4.00 & 47.57 \\
\hline Alcohol content & 6,875 & Percent & 12.57 & 11.00 & 14.50 \\
\hline Quantity sold (per week) & 6,875 & Bottles & 201.00 & 0.00 & $5,424.00$ \\
\hline \multicolumn{6}{|l|}{ Variety or blend } \\
\hline Chardonnay & 3,336 & Bottles & 13.86 & 6.95 & 47.57 \\
\hline Furmint & 111 & “ & 10.74 & 5.40 & 13.95 \\
\hline Grasevina & 122 & “ & 10.75 & 9.89 & 15.47 \\
\hline Harslevelu & 45 & “ & 9.64 & 9.28 & 9.99 \\
\hline Hemus & 58 & “ & 4.95 & 4.95 & 4.95 \\
\hline Muscat & 91 & “ & 13.93 & 9.28 & 15.42 \\
\hline Pinot Grigio & 305 & “ & 10.75 & 9.89 & 15.47 \\
\hline Sauvignon Blanc & 2,427 & “ & 12.11 & 5.20 & 28.99 \\
\hline Torrontes & 219 & “ & 10.07 & 7.17 & 12.50 \\
\hline Viognier & 214 & “ & 12.43 & 10.99 & 13.86 \\
\hline Other & 37 & “ & 14.39 & 4.85 & 17.45 \\
\hline \multicolumn{6}{|l|}{ Country of origin } \\
\hline Chile & 5,052 & Bottles & 13.07 & 4.90 & 47.57 \\
\hline Argentina & 1,209 & “ & 12.05 & 4.85 & 45.95 \\
\hline Croatia & 122 & “ & 10.75 & 9.89 & 15.47 \\
\hline Hungary & 497 & “ & 10.36 & 5.40 & 15.42 \\
\hline Bulgaria & 66 & “ & 5.05 & 4.00 & 6.95 \\
\hline \multicolumn{6}{|l|}{ Brand } \\
\hline Altivo & 92 & Bottles & 8.99 & 8.99 & 8.99 \\
\hline Boraszati & 92 & “ & 12.32 & 12.32 & 12.32 \\
\hline Calina & 106 & “ & 10.95 & 10.95 & 10.95 \\
\hline Caliterra & 216 & “ & 10.14 & 8.95 & 11.33 \\
\hline Vinas Carmen & 352 & “ & 15.62 & 13.50 & 19.95 \\
\hline Casablanca & 124 & “ & 11.79 & 10.99 & 13.50 \\
\hline Concha y Toro & 520 & “ & 12.41 & 5.20 & 23.55 \\
\hline Cono Sur & 106 & “ & 10.99 & 10.99 & 10.99 \\
\hline Cousino Macul & 134 & “ & 11.57 & 10.99 & 13.99 \\
\hline Degenfeld & 167 & “ & 11.21 & 5.40 & 15.42 \\
\hline Dona Paula & 103 & “ & 13.62 & 12.95 & 19.95 \\
\hline Dunavar & 108 & “ & 9.49 & 9.49 & 9.49 \\
\hline Errazuriz & 277 & “ & 11.60 & 9.95 & 14.95 \\
\hline Vina Esmeralda & 121 & “ & 28.24 & 19.95 & 45.90 \\
\hline Etchart & 95 & “ & 11.67 & 9.30 & 12.02 \\
\hline Hungarovin & 108 & “ & 8.48 & 8.48 & 8.48 \\
\hline Krizevacka & 103 & “ & 9.89 & 9.89 & 9.89 \\
\hline Lapostolle & 268 & “ & 18.45 & 15.45 & 27.49 \\
\hline Lurton & 108 & Bottles & 10.82 & 10.82 & 10.82 \\
\hline Marcus James & 108 & “ & 8.29 & 8.29 & 8.29 \\
\hline Miguel Torres & 154 & “ & 17.02 & 15.50 & 20.62 \\
\hline Montes & 108 & “ & 27.54 & 27.54 & 27.54 \\
\hline Penaflor & 216 & “ & 9.74 & 7.99 & 11.49 \\
\hline San Pedro & 222 & “ & 9.69 & 8.99 & 16.99 \\
\hline Santa Amelia & 80 & “ & 9.90 & 9.90 & 9.90 \\
\hline Santa Carolina & 198 & “ & 10.66 & 8.24 & 22.00 \\
\hline Santa Isabela & 216 & “ & 8.89 & 8.50 & 9.29 \\
\hline Santa Rita & 443 & “ & 13.76 & 11.99 & 28.99 \\
\hline Tarapaca & 201 & “ & 9.97 & 9.95 & 9.99 \\
\hline Tolten & 245 & “ & 12.37 & 9.95 & 19.50 \\
\hline Trivento & 215 & “ & 7.69 & 7.17 & 14.95 \\
\hline Undurraga & 174 & “ & 12.92 & 10.99 & 17.53 \\
\hline Valdivieso & 227 & “ & 14.72 & 11.99 & 47.57 \\
\hline Veramonte & 214 & “ & 15.99 & 15.99 & 15.99 \\
\hline Walnut Crest & 182 & “ & 10.43 & 10.26 & 10.45 \\
\hline Zuccardi & 108 & “ & 13.86 & 13.86 & 13.86 \\
\hline Other & 396 & “ & 12.61 & 4.00 & 23.99 \\
\hline
\end{tabular}


Table 4 Regression Results for the Red Wine Price Equation

\begin{tabular}{|c|c|c|c|}
\hline Variable category/Name & Estimated coefficient & Standard error & t-value \\
\hline Intercept & $1.349 * * *$ & 0.066 & 20.44 \\
\hline \multicolumn{4}{|l|}{ Variety } \\
\hline Bonarda & $0.229 * * *$ & 0.033 & 6.95 \\
\hline Cabernet Carmenere & $0.339 * * *$ & 0.033 & 10.02 \\
\hline Cabernet Malbec & $0.118 * * *$ & 0.014 & 8.25 \\
\hline Cabernet Merlot & $-0.082 * * *$ & 0.012 & -6.33 \\
\hline Cabernet Syrah & 0.024 & 0.014 & 1.62 \\
\hline Carmenere & $0.302 * * *$ & 0.020 & 14.89 \\
\hline Carmenere Merlot & $0.394 * * *$ & 0.022 & 17.86 \\
\hline Egri Bikaver & $0.170^{* * *}$ & 0.034 & 4.87 \\
\hline Gamza & $-0.354 * * *$ & 0.022 & -15.95 \\
\hline Kastelet & $-0.443 * * *$ & 0.056 & -7.80 \\
\hline Malbec Blend & $0.072 * * *$ & 0.027 & 2.59 \\
\hline Malbect & $0.048 * * *$ & 0.009 & 4.99 \\
\hline Merlot & $-0.066 * * *$ & 0.005 & -12.15 \\
\hline Merlot Malbec & $-0.178 * * *$ & 0.022 & -7.93 \\
\hline Merlot Mourvedre & $0.028 * * *$ & 0.010 & 2.66 \\
\hline Pinot Noir & $0.120 * * *$ & 0.018 & 6.40 \\
\hline Red Blend & $0.781^{* * *}$ & 0.030 & 25.64 \\
\hline Red Bordeaux Blend & $0.412 * * *$ & 0.027 & 15.03 \\
\hline Sangiovese Bonarda & $-0.300 * * *$ & 0.029 & -10.17 \\
\hline Syrah & $-0.045^{* * *}$ & 0.008 & -5.29 \\
\hline Other variety & $-0.451 * * *$ & 0.041 & -10.85 \\
\hline Quantity sold & $-0.102 * * *$ & 0.002 & -46.06 \\
\hline \multicolumn{4}{|l|}{ Season } \\
\hline Fall & $0.052 * * *$ & 0.005 & 9.30 \\
\hline Spring & $0.016^{* * *}$ & 0.005 & 3.03 \\
\hline Winter & $0.022 * * *$ & 0.005 & 3.90 \\
\hline Holidays & $0.026 * *$ & 0.012 & 2.12 \\
\hline Alcohol content & $0.131^{* * *}$ & 0.005 & 26.33 \\
\hline \multicolumn{4}{|l|}{ Country of origin } \\
\hline Argentina & $-0.187 * * *$ & 0.011 & -16.27 \\
\hline Hungary & $-0.364 * * *$ & 0.032 & -11.18 \\
\hline Croatia & $-0.192 * * *$ & 0.014 & -13.50 \\
\hline Bulgaria & $-0.847 * * *$ & 0.022 & -37.83 \\
\hline Holiday & $0.026 * *$ & 0.012 & 2.12 \\
\hline \multicolumn{4}{|l|}{ Brand } \\
\hline Aresti & $0.062 * * *$ & 0.018 & 0.000 \\
\hline Boyarda & $0.632 * * *$ & 0.023 & 27.26 \\
\hline Calina & $-0.581 * * *$ & 0.022 & -26.22 \\
\hline Caliterra & $-0.094 * * *$ & 0.013 & -7.06 \\
\hline Casa Rivas & -0.029 & 0.028 & -1.02 \\
\hline Casablanca & $-0.439 * * *$ & 0.018 & -23.67 \\
\hline Concha y Toro & $0.195 * * *$ & 0.012 & 16.24 \\
\hline Cono Sur & $-0.337 * * *$ & 0.012 & -26.54 \\
\hline Cousino Macul & $0.239 * * *$ & 0.013 & 18.33 \\
\hline Dalmcijavino & -0.023 & 0.058 & 0.68 \\
\hline Diego Murillo & $-0.023 * *$ & 0.011 & -2.02 \\
\hline Dona Flor & $-0.096 * * *$ & 0.023 & -4.08 \\
\hline Dona Paula & -0.008 & 0.015 & -0.55 \\
\hline Egervin & $0.185 * * *$ & 0.033 & 5.55 \\
\hline Errazuriz & $0.185^{* * *}$ & 0.014 & 13.09 \\
\hline Etchart & $0.189 * * *$ & 0.013 & 13.96 \\
\hline Finca Flichman & -0.000 & 0.015 & -0.03 \\
\hline Floresta & $0.395 * * *$ & 0.019 & 19.98 \\
\hline Grasevina & $-0.233 * * *$ & 0.009 & -23.42 \\
\hline Haras & $-0.103 * * *$ & 0.015 & -6.68 \\
\hline Kendall Jackson & $0.184 * * *$ & 0.041 & 4.46 \\
\hline Lapostolle & $0.361 * * *$ & 0.019 & 18.81 \\
\hline Lovico & $0.192 * * *$ & 0.028 & 6.73 \\
\hline Luigi Bosca & $0.395 * * *$ & 0.013 & 30.05 \\
\hline Lurton & $-0.317 * * *$ & 0.034 & -9.24 \\
\hline Marcus James & $0.025^{*}$ & 0.015 & 1.67 \\
\hline Miguel Torres & -0.009 & 0.019 & -0.49 \\
\hline Mont Grass & $0.243 * * *$ & 0.016 & 14.59 \\
\hline Nieto Setenier & -0.021 & 0.015 & -1.44 \\
\hline Odfjell & 0.021 & 0.016 & 1.29 \\
\hline
\end{tabular}




\begin{tabular}{lrrr}
\hline Variable category/Name & Estimated coefficient & Standard error & t-value \\
\hline Rothschild & -0.014 & 0.028 & -0.50 \\
San Pedro & $-0.121^{* * *}$ & 0.013 & -8.93 \\
Santa Rita & $0.149^{* * *}$ & 0.015 & 9.57 \\
Septima & $-0.149^{* * *}$ & 0.019 & -7.84 \\
Sierra Andina & $-0.337^{* * *}$ & 0.034 & -9.88 \\
Tarapaca & $-0.043^{* * *}$ & 0.011 & -3.86 \\
Trapiche & $0.267^{* * *}$ & 0.015 & 17.43 \\
Trivento & $-0.181^{* * *}$ & 0.024 & -7.39 \\
Undurraga & $0.094^{* * *}$ & 0.009 & 9.60 \\
Valentin Bianchi & $0.102^{* * *}$ & 0.015 & 6.76 \\
Veramonte & $0.176^{* * *}$ & 0.020 & 8.62 \\
Vina Bisquertt & $-0.330^{* * *}$ & 0.027 & -11.84 \\
Vina Carmen & $0.298^{* * *}$ & 0.014 & 21.17 \\
Vina Carolina & $-0.153^{* * *}$ & 0.012 & -12.27 \\
Vina Esmeralda & $0.560^{* * *}$ & 0.021 & 25.94 \\
Vina Rosa & $-0.381^{* * *}$ & 0.015 & -23.96 \\
Vinprom & $0.559^{* * *}$ & 0.024 & 22.48 \\
Weinert & $0.231^{* * *}$ & 0.028 & 8.02 \\
Zuccardi & -0.005 & 0.013 & -0.37 \\
Other & -0.004 & 0.018 & -0.27 \\
Adjusted R-square & 0.65 & & \\
F-value & $457.14^{* * *}$ & &
\end{tabular}

Note: ${ }^{*},{ }^{* *},{ }^{* *}$ denote significant estimates at the $0.10,0.05$, and 0.01 levels, respectively.

Changes in seasonal weather and holiday occasions appear to have an effect on prices of white wine. The estimated coefficients for all seasons are statistically significant. The fact that white wine is more likely to be consumed chilled makes it suitable for consumption during the summer in the temperate climate when the chilled wines may appeal to the consumers' taste particularly strong. As a result, wine consumption tends to decrease during the winter, which appears to cause a price discount compared to prices paid in the summer months. Alike the red wine sample, the alcohol content effect on white wine prices indicates BC consumers are willing to pay a premium for a higher alcohol content. However, the effect is smaller (three percent) in case of white wines as compared to the one estimated for red wines. The estimated coefficient of the quantity supports the negative relationship between white wine prices and the quantity of white wines sold.

\section{IMPLICTIONS AND CONCLUSIONS}

The current study applied a widely used methodological approach in wine price studies the hedonic pricing technique. The study expands the existing literature by estimating a hedonic price function for emerging wine suppliers in the BC market, especially from the Balkan countries. Results show that grape variety, brand name, country of origin, and alcohol content significantly affect prices and that $\mathrm{BC}$ consumers are willing to pay more for wines with some attributes. The result is consistent with the idea that consumers rely far more on objective characteristics that appear on labels than on subjective characteristics (Troncoso and Aguirre, 2006). In general, Chilean wines seem to be able to command high prices for their red and white wines. Compared to its wine producing neighbor, Argentina reports much lower price premiums, with the exception of wines made from
Malbec variety. According to Stein (2008), Malbec is Argentina's flagship variety and the main reason for the country's increasing popularity. Import data indicate considerably larger volume of wine imported from Chile than Argentina during the period considered in this study. Chilean wine industry has been focused on export markets for a prolonged period, whereas Argentinian wine industry has increased its wine exports only recently after the domestic market contracted (Stein, 2008). It is plausible that more established Chilean wines sell at a premium compared to wines from Argentina, but the American dollar-to-peso exchange rate might have also contributed to the observed price difference found in the current study.

BC consumers could expect significant price discounts for wines imported from counties in Central Europe and the Balkans indicating the low value perception of these wines compared to those from the New World. Even though the Bulgarian Hemus and Gamza along with the Croatin Kastelet are competitively priced, consumers might see low prices as a signal for inferior quality wines. Moreover, the fact that wine quality and image were neglected under the years of Communism hindered the ability of the producers from those countries to build a worldwide reputation. A seminal paper by Akerlof (1970) argues that a firm cannot charge a premium for a high-quality product if consumers do not have full information on product quality. Even though that study applied to the automobile market, it can easily extend to the wine market. It can be argued that BC consumers lack information about native grape varieties that originate from countries like Bulgaria, Croatia or Hungary, and as a result, are unable to value them as they value varieties commonly known to them. On the other hand, Chilean wines have been able to build their reputation and, therefore, command higher prices. 
Table 5 Regression Results of the White Wine Price Equation

\begin{tabular}{|c|c|c|c|}
\hline Variable category/Name & Estimated coefficient & Standard error & t-value \\
\hline Intercept & $2.093 * * *$ & 0.085 & 24.48 \\
\hline \multicolumn{4}{|l|}{ Variety } \\
\hline Furmint & $-0.714 * * *$ & 0.050 & -14.09 \\
\hline Haraslevu & $-0.413 * * *$ & 0.027 & -10.70 \\
\hline Hemus & $-0.298 * * *$ & 0.028 & -10.89 \\
\hline Muscat & $0.133^{* * *}$ & 0.022 & 5.86 \\
\hline Pinot Grigio & 0.004 & 0.039 & 0.10 \\
\hline Sauvignon Blanc & $-0.026 * * *$ & 0.004 & -5.54 \\
\hline Sauvignon Semillon & $-0.345^{* * *}$ & 0.005 & -68.07 \\
\hline Torrontes & $-0.081 * * *$ & 0.017 & -4.74 \\
\hline Viognier & $0.180 * * *$ & 0.040 & 4.47 \\
\hline Other & $-0.477 * * *$ & 0.135 & -3.52 \\
\hline Quantity & $-0.041 * * *$ & 0.002 & -18.28 \\
\hline \multicolumn{4}{|l|}{ Season } \\
\hline Fall & $0.015^{* * *}$ & 0.004 & 3.42 \\
\hline Spring & $0.011 * *$ & 0.004 & 2.44 \\
\hline Winter & $-0.010^{* *}$ & 0.004 & -2.04 \\
\hline Holiday & $0.028 * *$ & 0.011 & 2.43 \\
\hline Alcohol & $0.045^{* * *}$ & 0.006 & 7.15 \\
\hline \multicolumn{4}{|l|}{ Country } \\
\hline Argentina & $-0.135^{* *}$ & 0.039 & -3.44 \\
\hline Croatia & $-0.191 * * *$ & 0.020 & -9.34 \\
\hline Bulgaria & $-0.547 * * *$ & 0.021 & -25.17 \\
\hline Hungary & $-0.376 * * *$ & 0.012 & -30.20 \\
\hline \multicolumn{4}{|l|}{ Brand } \\
\hline Altivo & $-0.317 * * *$ & 0.039 & -8.03 \\
\hline Boraszati & $0.337 * * *$ & 0.008 & 39.98 \\
\hline Calina & $-0.280 * * *$ & 0.013 & -20.98 \\
\hline Caliterra & $-0.143^{* * *}$ & 0.013 & -10.40 \\
\hline Casablanca & $-0.187 * * *$ & 0.014 & -13.37 \\
\hline Cono Sur & $-0.283^{* * *}$ & 0.039 & -7.09 \\
\hline Cousino Macul & $-0.09 * * *$ & 0.013 & -6.96 \\
\hline Degenfeld & $0.435^{* * *}$ & 0.024 & 17.28 \\
\hline Dona Flor & 0.010 & 0.038 & 0.27 \\
\hline Dona Paula & 0.058 & 0.041 & 1.41 \\
\hline Dunavar & $0.349 * * *$ & 0.039 & 8.78 \\
\hline Errazuriz & $-0.067 * * *$ & 0.010 & -6.23 \\
\hline Etchart & -0.023 & 0.046 & -0.52 \\
\hline Hungarovin & $0.349 * * *$ & 0.039 & 8.78 \\
\hline Krizevacka & $0.455^{* * *}$ & 0.022 & -20.68 \\
\hline Lapostolle & $0.250 * * *$ & 0.019 & 12.90 \\
\hline Lurton & $-0.349 * * *$ & 0.030 & -8.78 \\
\hline Marcus James & $-0.212 * * *$ & 0.039 & -5.39 \\
\hline Miguel Torres & $0.263^{* * *}$ & 0.012 & 21.53 \\
\hline Mont Grass & $0.644^{* * *}$ & 0.012 & 44.28 \\
\hline San Pedro & $-0.232 * * *$ & 0.0124 & -18.72 \\
\hline Santa Amelia & $-0.315 * * *$ & 0.0123 & -25.56 \\
\hline Santa Carolina & $-0.213 * * *$ & 0.0148 & -14.35 \\
\hline Santa Isabel & $-0.241^{* * *}$ & 0.010 & -23.43 \\
\hline Santa Rita & $0.095 * * *$ & 0.013 & 7.03 \\
\hline Tarapaca & $-0.170 * * *$ & 0.010 & -16.41 \\
\hline Tolten & $-0.067 * * *$ & 0.014 & -4.57 \\
\hline Trivento & $-0.372 * * *$ & 0.039 & -9.50 \\
\hline Undurraga & 0.006 & 0.011 & 0.54 \\
\hline Valdivieso & $0.043 * *$ & 0.018 & 2.29 \\
\hline Veramonte & $0.215^{* * *}$ & 0.009 & 22.48 \\
\hline Vina Esmeralda & $0.704^{* * *}$ & 0.047 & 14.75 \\
\hline Vinas Carmen & $0.231 * * *$ & 0.011 & 20.44 \\
\hline Walnut Crest & $-0.184 * * *$ & 0.010 & -17.20 \\
\hline Zuccardi & $0.283^{* * *}$ & 0.039 & 7.09 \\
\hline Other & $-0.070 * * *$ & 0.019 & 12.90 \\
\hline Adjusted R-square & 0.79 & & \\
\hline F-value & $472.04 * * *$ & & \\
\hline
\end{tabular}

Note: $*, * *, * * *$ denote significant estimates at the $0.10,0.05$, and 0.01 levels, respectively. 
Because the world wine market witnesses the entry of new suppliers, product differentiation will play an increasingly important role. The results of this study suggest that the choice of the variety or brand name can have considerable implications to the commercial success of a producer. Moreover, understanding how consumers assess wine's objective attributes helps both marketers and producers from emerging countries to efficiently differentiate their product. It is thus fair to stress that the current study should be complemented with further exploration of wine characteristics that may affect wine prices from the emerging suppliers. As suitable data become available vintage, role of experts' rating, and the geographical area indication may be tested and allow to derive additional practical recommendations for wine producers and distributors in BC and elsewhere.

\section{REFERENCES}

Agriculture and Agri-Food Canada. 2009. The Canadian Wine Industry. Ottawa, Ontario.

AKERLOF, G. A. 1970. "The Market for Lemons: Quality, Uncertainty and the Market for Mechanism.” Quarterly Journal of Economics 84:488-500. doi:10.2307/1879431

BELSLEY, D., KUH, E. and WELSCH, R. 1980. Regression Diagnostics: Identifying Influential Data and Sources of Collinearity, New York: John Wiley.

BENFRATELLO, L., M. PIACENZA and SACCHETTO, S. 2009. “Taste or Reputation: What Drives Market Prices in the Wine Industry? Estimation of a Hedonic Model for Italian Premium Wines.” Applied Economics 41:197-209. DOI: $10.1080 / 00036840701222439$

British Columbia Liquor Distribution Branch. 2007. Annual Report, 2006-2007. Vancouver, British Columbia.

British Columbia Wine Institute. 2011. BC Wine. Kelowna, British Columbia.

CAREW, R., and FLORKOWSKI, W.J. 2008. The Importance of Australian Corporate Brand and Grape Varietal Wines: Hedonic Pricing in the British Columbia Wine Market. Journal of Wine Economics, 3(2): 194204. DOI: $10.1017 / S 1931436100001218$

CAREW, R. and FLORKOWSKI, W.J. 2010. "The Importance of Geographic Wine Appellations: Hedonic Pricing of Burgundy Wines in the British Columbia Wine Market." Canadian Journal of Agricultural Economics 58:93-108. DOI: $\quad 10.1111 / \mathrm{j} .1744-$ 7976.2009.01160.x

COMBRIS, P., LECOCQ, S. and VISSER, M. 1997. "Estimation of an Hedonic Price Equation for Bordeaux Wine: Does Quality Matter?” The Economic Journal, 107:390-402. DOI: $10.1111 / \mathrm{j} .0013-0133.1997 .165 . \mathrm{X}$ COSTANIGRO, M., MCCLUSKEY, J. and R. MITTELHAMMER. 2007. "Segmenting the Wine Market Based on Price: Hedonic Regression When Different Prices Mean Different Products.” Journal of Agricultural Economics 58(3):454-66. DOI: 10.1111/j.1477-9552.2007.00118.x

FOSTER, M., - SPENCER, D. 2002. "World Wine Market: Barriers to Increasing Trade.” ABARE Research Report 02.6.
GOLAN, A. and SHALIT, H. 1993. "Wine Quality Differentials in Hedonic Grape Pricing." Journal of Agricultural Economics, 44(2):311-321. DOI: 10.1111/j.1477-9552.1993.tb00274.x

Industry Canada. Trade data online. Available online at https://www.ic.gc.ca/app/scr/tdst/tdo/crtr.html (accessed October 18, 2015).

KWONG, L.M.K., CYR, D., KUSHNER, J. and TOMSON, O. 2010. “A Semiparametric Hedonic Pricing Model on Ontario Wines." Canadian Journal of Agricultural Economics 58:1-21. DOI: 10.1111/j.17447976.2010.01209.x

LANDON, S. and SMITH, C. 1997. "The Use of Quality and Reputation Indicators by Consumers: The Case of Bordeaux Wine.” Journal of Consumer Policy, 20:289323. DOI: $\underline{10.1023 / \mathrm{A}: 1006830218392}$

LANDON, S. and SMITH, C. 1998. "Quality Expectations, Reputation and Price.” Southern Economic Journal 64(3):628-647. DOI: 10.2307/1060783

LUPPE, M.R., FAVERO, L.P.L. and BELFIORE, P.P. 2009. "Hedonic Pricing Models and the Evaluation of attributes: The Case of Wines from Brazil, Argentina and Chile.” Economic and Business Journal 134:27-47.

NERLOVE, M. 1995. "Hedonic Price Functions and the Measurement of Preferences: The Case of Swedish Wine Consumers." European Economic Review, 39:16971716. DOI: $10.1016 / 0014-2921(95) 00013-5$

NOEV, N. 2005. "Wine quality and regional reputation: Hedonic analysis of the Bulgarian wine market.” Eastern European Economics 43(6):5-30. DOI:10.2753/EEE0012-8755430601

NOEV, N. and SWINNEN, J. F.M. 2001. "The Transition of the Wine Industry, Policy, Trade in Eastern Europe and the Former Soviet Union.” The World's Wine Markets: Globalization at Work.” Edward Elgar: London 161-184.

OCZKOWSKI, E. 1994. “A Hedonic Price function for Australian Premium Table Wine. Australian Journal of Agricultural Economics 38(1):93-110. DOI: 10.1111/j.1467-8489.1994.tb00721.x

OCZKOWSKI, E. 2001. "Hedonic Wine Price Functions and Measurement Error." The Economic Record, 77(239):374-382. DOI: 10.1111/1475-4932.00030

ORTUZAR-GANA, J.C. and ALFRANCA-BURRIEL, O. 2010. "Current and Regular Prices Hedonic Models for the Wine Industry.” Spanish Journal of Agricultural Research, 8(4):873-886. DOI: 10.5424/sjar/20100841381

ROSEN, S.M. 1974. "Hedonic Prices and Implicit Markets: Product Differentiation in Pure Competition.” Journal of Political Economy 82:34-55. Stable URL: http://www.jstor.org/stable/1830899

SAN MARTIN, G. J., B. BRUMMER, and TRONCOSO, J.L. 2008. "Determinants of Argentinean Wine Prices in the U.S. market.” American Association of Wine Economists. AAWE Working Paper. No 15. [www.wine-economics.org].

SCHAMEL, G. and ANDERSON, K. 2003. "Wine Quality and Varietal, Regional and Winery Reputation: Hedonic Prices for Australia and New Zealand." The Economic Record, 79 (September):357-369. DOI: $\underline{10.1111 / 1475-4932.00109}$ 
SHAPIRO, C. 1983. "Premiums for High Quality Products as Returns to Reputations.” Quarterly Journal of Economics 98:659-679. doi:10.2307/1881782

SIDLOVITS, D. and KATOR, Z. 2007. "Characteristics of Vertical Coordination in the Hungarian Wine Sector." Paper prepared for the $104^{\text {th }}$ European Agricultural Economics Association Seminar: Agricultural Economics and Transition. Budapest, Hungary, September 6-8, 2008.

Statistics Canada. 2005. Consumer Price Index (CPI), Wine Purchased from Retail Stores, $(2002=100)$. Table 326-0020. Available online at http://estat.statcan.ca/cgiwin/CNSMCGI.EXE .

Statistics Canada. 2011. Table 183-0015-Sales of alcoholic beverages of liquor authorities, wineries and breweries, by value and volume, fiscal years ended March 31; Table 051-0001-Population of British Columbia 18 years and over.

http://estat.statcan.gc.ca/cgi-win/cnsmchi.exe? (Accessed May 5 2010).

STEIN, S. 2008. “Our Saviors May not Speak Spanish: Changing Markets and Strategies in Argentina's Wine Revolution, 1990-2008." American Association of Wine Economists AAWE Working Paper No. 21. http://www.wineeconomics.org/workingpapers/AAWE_WP21.pdf/

(Accessed April 27, 2011).

STEINER, B.E. 2004. "Australian Wines in the British Wine Market: A Hedonic Price Analysis.” Agribusiness 20(3):287-307. DOI: 10.1002/agr.20012

TRONCOSO, J. L. and AGUIRRE, M. 2006. "Short Communication. Price Determinants of Chilean Wines in the U.S. Market: A Hedonic Approach.” Spanish Journal of Agricultural Research, 4(2):124-129. DOI: 10.5424/sjar/2006042-191

VAN TIENHOVEN, A. 2008. The Global Wine Industry: How Small Chilean Wineries Should Compete. Centre for Latin American Research and Documentation, Amsterdam, the Netherlands.

WAUGH, F. 1928. "Quality Factors Influencing Vegetable Prices." Journal of Farm Economics 10(2):185-196.

WILLIAMS, P. W. and DOSSA, K.B. 2003. "Nonresident Wine Tourist Markets: Implications for British Columbia's Emerging Wine Tourism Industry.” Journal of Travel, Tourism and Marketing, 14(3/4):1-34. DOI: 10.1300/J073v14n03 01

YUE, C., MARETTE, S. and BEGHIN, J.C. 2006. "How to Promote Quality Perception in Wine Markets: Brand Advertising or Geographical Indication?” Working Paper 06-WP-426 Iowa State University, Center for Agricultural and Rural Development. 